УДК 781.1+786

DOI https://doi.org/10.24919/2308-4863/34-2-11

Яніна ЛИСЕНКО,

orcid.org/0000-0002-3879-7989

кандидат мистецтвознавства,

декан музичного факультету

Дніпропетровської академї̈ музики імені Михайла Глінки (Дніпро, Україна) lysenkoanina949@gmail.com

Ольга ЖУКОВА, orcid.org/0000-0002-2931-018X викладач кафедри фортепіано

Дніпропетровськоӥ академї музики імені Михайла Глінки (Дніпро, Україна) olechka-musika@mail.ru

\title{
РОЛЬ ВИКОНАВСЬКОЇ КУЛЬТУРИ МОЛОДОГО МИТЦЯ КАФЕДРИ «ФОРТЕПІАНО» ДНІПРОПЕТРОВСЬКОЇ АКАДЕМІЇ МУЗИКИ IМЕНІ М. ГЛІНКИ
}

У статті висвітлено роль виконавської культури молодого мития кафедри «Фортепіано» Дніпропетровської академії музики імені М. Глінки.

Проаналізовано наукові дослідження з цього питання. Виявлено, щчо особливості означеного феномена передбачають придбання в навчальному прочесі морально-естетичних иінностей, які засновані на мистеиьких традииіях Дніпропетровської фортепіанної школи, щзо дає змогу розкрити значення особистісних иінностей молодого мития як стрижня його особи, щчо забезпечує саморозвиток. У зв'язку з цим особливої актуальності набуває формування виконавської культури майбутніх музикантів у навчальному проиесі кафедри «Фортепіано» Дніпропетровської академії музики імені М. Глінки. Актуалізовано, щзо історичний досвід концертно-виконавської та педагогічної діяльності видатних піаністів-педагогів Дніпропетровщчини впливають на сучасну виконавську культуру молодих митиів кафедри «Фортепіано», є гармонійним поєднанням професійних знань, навичок та вмінь.

Визначено, щео виконавська культура молодих митців кафедри «Фортепіано» Дніпропетровської академії музики імені М. Глінки передбачає визначення шляхів та засобів послідовного, систематичного й цілеспрямованого формування професіоналізму майбутніх музикантів.

Узагальнюючи вищезазначене, ми доходимо до висновку, щзо виконавська культура молодих митців кафедри «Фортепіано» Дніпропетровської академії музики імені М. Глінки сприяє зростанню рівнів сформованості головних, найбільш значущих иінностей духовної культури майбутніх музикантів-піаністів, а саме: иіннісної спрямованості до виконавської діяльності та сформованості музичної культури особистості, збереження та розвитку традииій фортепіанного мистецттва, виховання гуманістичного типу особистості студента. 3 точки зору професійної підготовки музикантів виконавська культура молодих митиів кафедри "Фортепіано» Дніпропетровської академії музики імені М. Глінки набуває статусу відкритої системи в художньому просторі глобалізованої культури ХХІ століття.

Ключові слова: виконавська культура, фортепіанна школа, піаністи, Дніпропетровська академія музики імені М. Глінки. 
Yanina LYSENKO, orcid.org/0000-0002-3879-7989

Candidate of Art History,

Dean of the Music Faculty

M. Glinka Dnipropetrovsk Academy of Music (Dnipro,Ukraine)lysenkoanina949@gmail.com

Olha ZHUKOVA, Lecturer at the Piano Department M. Glinka Dnipropetrovsk Academy of Music (Dnipro,Ukraine) olechka-musika@mail.ru

\section{THE ROLE OF PERFORMANCE CULTURE OF A YOUNG ARTIST OF THE PIANO DEPARTMENT OF DNIPROPETROVSK M. HLINKA MUSIC ACADEMY}

In the article it is highlighted the role of performing culture of the young artist of the Piano Department of Dnipropetrovsk M. Hlinka Music Academy.

The scientific researches on this issue are analyzed. It is revealed that the peculiarities of this phenomenon involve the acquisition in the educational process of moral and aesthetic values, which are based on the artistic traditions of the Dnipropetrovsk piano school, which allows to reveal the role of personal values of the young artist as the core of his personality that provides his or her self-development.

In this regard, the formation of future musicians\&apos, performing culture in the educational process of the Department of Piano of Dnipropetrovsk M. Hlinka Music Academy becomes especially important. It is updated that the historical experience of concert-performing and pedagogical activity of outstanding pianists-pedagogues of Dnipropetrovsk region influences the modern performing culture of young artists of the Piano Department, is a harmonious combination of professional knowledge, skills and abilities.

It is determined that the performing culture of young artists of the Piano Department of Dnipropetrovsk M. Hlinka Music Academy involves identifying ways and means of consistent, systematic and purposeful formation of future musicians\&apos, professionalism.

Summarizing the above mentioned, we can conclude that the role of performing culture of young artists of the Department of Piano of Dnipropetrovsk M. Hlinka Music Academy contributes to the growth of the main, most important values of spiritual culture of future pianists, namely: value orientation to performance and formation of musical culture of the individual, preservation and development of piano art traditions, education of the humanistic type of the student\&apos personality. From the point of view of professional training of musicians, the performing culture of young artists of the Piano Department of Dnipropetrovsk M. Hlinka Music Academy acquires the status of an open system in the artistic space of globalized culture of the XXI century.

Key words: performing culture, piano school, pianists, Dnipropetrovsk M. Hlinka Music Academy.

Постановка проблеми. XX - початок XXI століття - це епоха становлення і розвитку музичної культури України. Сучасні українські вчені трактують культуру як «феномен духовного порядку, наслідок і вияв творчої діяльності в галузі науки, мистецтва, релігії, права тощо» (Лекції з історії вітчизняної та світової культурології, 2005: 7). Особливу увагу привертає така теза: «Культура була і залишається середовищем, в якому відбувається розвиток, удосконалення одухотворення людини, соціалізація людської особистості, тобто залучення індивіда до системи цінностей, що визначальні для певної спільноти, нації, людства. Людина є творінням культури і водночас іiі творцем. Накопичення культури - це поступ людини на шляху до Істини, Добра та Краси» (Лекції 3 історії вітчизняної та світової культурології, 2005: 13-14). Тобто формування і розвиток особистості відбувається в середовищі, яке окреслене як культурне.
Нові вимоги до особистості музиканта, його професійних компетенцій становлять невід'ємну складову частину музично-культурного процесу. Формування виконавської культури молодих митців музичного мистецтва зумовлене істотними змінами соціокультурних умов, що полягають в утвердженні особистісної значущості їх професійного зростання, новому баченні завдань, які покладаються на майбутнього професійного виконавця.

Аналіз досліджень. Аналіз історичних, науково-теоретичних, музично-педагогічних, мистецтвознавчих джерел дає змогу констатувати, що до визначення розвитку української музичної виконавської культури різні автори підходили з власних принципових позицій та інтелектуально-творчих поглядів у контексті громадсько-політичних, західноєвропейських подій музичної культури. Над розкриттям проблем української фортепіанної школи XX століття, творчої діяльності видатних iï постатей працювали в різні роки В. Клин, 
Г. Коган, О. Кононова, Л. Лисенко, Л. Мазепа, В. Макаров, Л. Масол, Л. Попова, Л. Ніколаєв, Т. Рощіна, Н. Руденко, В. Сирятський, О. Скляров, Н. Смоляга, О. Снєгірьов, Т. Старук, М. Степаненко та інші. Визначену проблему розглянуто на прикладі розвитку національної музично-педагогічної ідеї та іiї послідовників у різні історичні періоди впродовж XX століття, мистецтва фортепіанного виконавства, творчої діяльності визначних піаністів-педагогів провідних музичних закладів України (В. Барвінський, Р. Горовиць, Г. Левицька, П. Луценко, А. Луфер, К. Михайлов, Л. Мюнцер, Г. Нейгауз, В. Пухальський, Р. Савицький, М. Старкова, Б. Яворський та інші).

Мета статті - проаналізувати та висвітлити роль виконавської культури молодого митця кафедри «Фортепіано» Дніпропетровської академії музики імені М. Глінки.

Виклад основного матеріалу. Протягом свого існування фортепіанна школа Дніпропетровської академії музики імені М. Глінки виконувала функцію творення виконавської культури України, виявляючи певні можливості в розвитку музичного мистецтва. У кожну історичну епоху народжувались нові погляди, які своєрідно усвідомлювались суспільством відповідно до актуальних проблем свого часу, певних запитів. Відкритість українських музикантів до європейського досвіду музичного просвітництва сприяла розвитку вітчизняної практики поширення найбільш яскравих досягнень тогочасної музичної культури. Значну роль відіграє в цьому процесі виконавство як одна 3 провідних форм просвітництва XIX століття: центрами сольного концертного фортепіанного музикування були Житомир та Харків (Лисенко, 2017).

Сучасну музику того періоду пропагували переважно російські та західноєвропейські музиканти: С. Рахманінов, О. Скрябін, Є. Танеєв, О. Гольденвейзер, В. Тіманова, В. Сапельников, Л. Головський, І. Падеревський, А. Рубенштейн, Г. Гальстон, О. Боровський, О. Габрилович та ін. (Історія української та зарубіжної культури, 1999: 119-120).

На прикладі історико-педагогічного досвіду піаністів Дніпропетровської академії музики імені М. Глінки науковець сучасності Н. Гуральник визначає роль виконавської культури в навчальному процесі молодих митців: 1) дотримання відповідного набору виконуваних творів використання шедеврів світової фортепіанної музики, створених у різні історичні періоди; виконання фортепіанних творів за стильовим принципом; 2) збагачення музичного репертуару шляхом вивчення української фортепіанної класики;
3) продовження традицій через безпосереднє опанування і використання у виконавсько-педагогічній практиці зразків музики сучасних українських композиторів; 4) дотримання принципу художньої довершеності; збереження духу просвітництва як аксіологічного компонента виховання духовної особистості піаніста (Гуральник, 2007: 32).

Музикознавці, педагоги, видатні діячі фортепіанної школи Дніпропетровської консерваторії імені М. Глінки глибоко усвідомлювали обсяг і роль виконавської культури. Серед яскравої плеяди піаністів, виконавців, педагогів Дніпропетровщини були М. Оберман, С. Грібановська, М. Левін, Р. Лисенко, М. Гейман, М. Гордон, Л. Свсевська та багато інших.

Так, яскравою сторінкою історії Дніпропетровської фортепіанної школи була визначна піаністка М. Гейман, виконавська діяльність та культура котрої охоплювала неосяжний період. 31918 по 1978 роки М. Гейман була ведучим педагогом училища, послідовницею школи Т. Лепетитського, А. Єсипової, І. Венгерової на Дніпропетровщині. Творча діяльність М. Гейман становить цілу епоху в розвитку піаністичної культури цього регіону. Виконавсько-педагогічні досягнення М. Гейман це високий професійний статус більшості ії учнів, які нині зберігають, продовжують і примножують принципи піаністичної школи музикантів у багатьох країнах: Україні, Росії, Німеччині, Ізраїлі, США, Канаді, Франції тощо (Медведникова, 2011).

Особливо варто підкреслити багаторічну просвітницьку і виконавську діяльність на Дніпропетровщині піаніста, педагога, музичного діяча P. Лисенко. Дніпропетровці мали змогу почути в iii інтерпретації кращі зразки фортепіанної творчості західноєвропейських композиторів - Л. Бетховена, Ф. Шопена, Ф. Ліста, Р. Шумана. Характерною тенденцією концертно-виконавської культури Р. Лисенко є переважне звернення до фортепіанної творчості українських композиторів, які спиралися на глибоке знання музичного фольклору українського народу. Піаністка знаходила рукописи і першою виконувала музичні твори Я. Степового, Л. Ревуцького, В. Косенка, Н. Дремлюги, Н. Сільванського, О. Коломійця, стала першим виконавцем «Рух у варіаціях» для фортепіано 3 оркестром С. Людкевича. «Піаністична інтонація Ради Лисенко неповторна - щира, добра, дещо задумлива. Ї̈ї характеризує дуже гнучке фразування, тонке відчуття музичного часу, коли виконавський темпоритм зразу ж чуйно реагує на кожен мелодійний чи гармонійний відтінок розвитку» (Медведникова, 2013: 18). Виконавська культура Р. Лисенко є зразком романтич- 
ного стилю, який відрізняє яскрава емоційність, наповнена виконавською волею, багатопланове володіння фактурою, багатство звукових темброво-динамічних фарб. Усі ці способи музичної виразності у виконанні піаністки Р. Лисенко були спрямовані на повне розкриття авторського задуму.

Однією 3 вихованок Дніпропетровського музичного училища була піаністка, педагог, музично-громадський діяч - С. В. Грибановська. Ї̈̈ пам'ятають як талановитого музиканта, цілком відданою музиці і рідному краю. Техніка, виконавська культура, якою володіла Світлана Володимирівна, визначена в педагогічної діяльності, який вона віддала чотири десятиріччя свого життя, 3 1947 по 1987 рік. Педагог С. Грибановська викладала різноманітні навчальні дисципліни фортепіанної спеціалізації: спеціальне фортепіано, камерний і фортепіанний ансамблі, педагогічна i виконавська практика. Значну частину сил і часу ведучий педагог віддавала навчально-методичної роботи, в тому числі організації та проведення щомісячних методичних семінарів для викладачів районних і сільських дитячих музичних шкіл області, прослуховування випускників цих шкіл і додання їм практичної допомоги викладачами фортепіанного відділу училища. Іншим напрямом творчої діяльності С. Грибановської була підготовка учнів класу до концертно-виконавської практики. Завдяки ії зусиллям здійснювалися щорічні гастрольні поїздки учнів у сільську місцевість та в інші міста області (наприклад, пгт Царичанка, м. Нікополь). Концертні виступи учнів С. Грибановської супроводжувалися невеликими розповідями про особливості творчості цього композитора, короткими анотаціями до кожного виконуваного твору (Медведникова, 2006: 9-10).

Вагомим підгрунтям для Дніпропетровської школи піанізму стала діяльність випускника Петербурзької консерваторії, учня Л. Ніколаева і С. Савшинського - М. Левіна як педагога. 31923 по 1927 рік М. Левін працював викладачем кафедри фортепіано Ленінградської консерваторії ім. Н.А. Римського-Корсакова, продовжував навчання в якості аспіранта. В ці роки М. Левін вперше на високому рівні займається педагогічною роботою. Значну частину часу займала виконавська робота, піаніст часто виступає як із сольними концертами, так і в ансамблях. У зв'язку з відкриттям в Катеринославі консерваторії, яка в 1923 році була реорганізована в музичний технікум зі статусом вищого навчального закладу, М. Левін отримує запрошення до Дніпропетровська. 3 цього моменту 1927 і по 1968 рік його творча і педагогічна діяльність повністю пов'язана 3 колективом
Дніпропетровської консерваторії імені М. Глінки. Активна виконавська діяльність обмежувалася масштабами України і Дніпропетровщини. Доходимо висновку, що виконавська культура та педагогічна діяльність піаніста, педагога, музичного діяча М. Левіна сприяла розвитку Дніпропетровської піаністичної школи як складника української піаністичної культури (Медведникова, 2014).

Яскравою сторінкою музичної культури Дніпропетровської академії музики імені М. Глінки є виконавський стиль М. Гордон, який відрізнявся глибокою емоційністю, інтонаційною виразністю, рельєфністю методичний ліній. Особливо цінна якість іiі виконавської культури - це ставлення до звука як до основного засобу музичної виразності. М. Гордон володіла різноманітною палітрою звукових фарб в єдності з їх темброво-динамічними нюансами. Звук інструменту набував рідкісну об'ємність (Медведникова, 2008: 40).

Поряд із такими яскравими i різноплановими музикантами, як М. Ліберман, М. Оберман, Г. Єрошкін, С. Грибановська, ніколи не втрачала своєї індивідуального фортепіанного стилю Л. Свсевська. Ї̈ї виконавська культура, естетика iï піанізму полягала в зовнішній строгості, простоті, економності рухів. Технічна досконалість, віртуозність потрібні були тільки для досягнення художніх завдань. I перше враження було таке, що ії піанізм - це піанізм класичного типу. Але насправді ця суворість i доцільність рухів гармонійно поєднувалися із щирою, глибокою виразністю i яскравою емоційністю в художньому композиторському задумі (Медведникова, 2007: 30-31).

Доречно зазначити, що разом з іншими факторами роль виконавської культури молодих митців кафедри «Фортепіано» Дніпропетровської академії музики імені М. Глінки є суб'єктом культуротворення у суспільстві за рахунок поширення його змісту, високого професійного рівня педагогів і студентів, усвідомлення музикантами своєї культуротворчої місії. Отже, феноменологічний підхід, який використовують педагоги в навчальному процесі майбутніх піаністів Дніпропетровської академії музики імені М. Глінки, дає змогу виявити роль виконавської культури молодих митців, від якої залежить започаткування сталої традиції виконання фортепіанних творів. Орієнтація виконавця на чуттєвий контакт з інструментом (відтворення звукового фортепіано) в процесі інтерпретації фортепіанних творів слугує механізмом творчого моделювання принципів композиторського мислення.

Таким чином, із часом роль виконавської культури піаністів кафедри «Фортепіано» у Дніпропетровській академії музики імені М. Глінки 
постійно удосконалювалась, iї основи закладені у творчій діяльності та навчальному процесі видатних педагогів-музикантів.

Висновки. Узагальнюючи вищезазначене, маємо підстави стверджувати, що фортепіанний стиль, педагогічний досвід видатних піаністів Дніпропетровської академії музики імені М. Глінки - феноменальне явище виконавської культури нашої держави. Відтворення виконав- ської культури молодих митців кафедри «Фортепіано» Дніпропетровської академії музики імені М. Глінки $\epsilon$ шляхом розуміння феноменології. 3 точки зору професійної підготовки музикантів виконавська культура молодих митців кафедри «Фортепіано» Дніпропетровської академії музики імені М. Глінки набуває статусу відкритої системи в художньому просторі глобалізованої культури XXI століття.

\section{СПИСОК ВИКОРИСТАНИХ ДЖЕРЕЛ}

1. Гуральник Н. П. Українська фортепіанна школа XX століття в контексті розвитку музичної педагогіки : історико-методологічні та теоретико-технологічні аспекти : монографія. Київ : Національний педагогічний університет імені М. П. Драгоманова, 2007. 460 с.

2. Історія української та зарубіжної культури : навчальний посібник / за ред. С. М. Клапчука, В. Ф. Остафійчука. Київ : Вища школа. 1999. 326 с.

3. Лекції з історії вітчизняної та світової культурології / А. Яртись, В. Мельник. Львів : Світ, 2005. 567с.

4. Лисенко Я. О. Музичне просвітництво Дніпропетровщини 50-70-х років : монографія. Дніпро: ЛІРА, 2017. 184 с.

5. Медведникова Т. Мария Гейман. Выдющиеся музыканты Днепропетровщины. Днепропетровск : Днепропетровская консерватория имени М. Глинки, 2011. 180 с.

6. Медведникова Т. Мариам Гордон. Выдющиеся музыканты Днепропетровщины. Днепропетровск : Днепропетровская консерватория имени М. Глинки, 2008. С.40.

7. Медведникова Т. Светлана Грибановская. Выдющиеся музыканты Днепропетровщины. Днепропетровск : Днепропетровская консерватория имени М. Глинки, 2006. С. 9-10.

8. Медведникова Т. Лидия Евсевская. Выдющиеся музыканты Днепропетровщины. Днепропетровск : Днепропетровская консерватория имени М. Глинки, 2007. С. 30-31.

9. Медведникова Т. Моисей Левин. Выдющиеся музыканты Днепропетровщины. Днепропетровск: Днепропетровская консерватория имени М. Глинки, 2014. 199 с.

10. Медведникова Т. Михаил Оберман. Выдющиеся музыканты Днепропетровщины. Днепропетровск : Днепропетровская консерватория имени М. Глинки, 2013. 198 с.

\section{REFERENCES}

1. Guralnik N. Ukrayins'ka fortepianna shkola XX stolittya v konteksti rozvytku muzychnoyi pedahohiky: istoryko-metodolohichni ta teoretyko-tekhnolohichni aspekty : monohrafiya [Ukrainian piano school of the twentieth century in the context of the development of music pedagogy: historical, methodological and theoretical-technological aspects. Monograph] Kyiv. 2007. 460 p. [in Ukranian].

2. Istoriya ukrayins'koyi ta zarubizhnoyi kul'tury: navchal'nyy posibnyk [History of Ukrainian and foreign culture] Kyiv: Higher School. 1999. 326 p. [in Ukranian].

3. Lektsiyi z istoriyi vitchyznyanoyi ta svitovoyi kul'turolohiyi [Lectures on the history of national and world culturology] Lviv: Svit, 2005. 567 p. [in Ukranian].

4. Lysenko J. Muzychne prosvitnytstvo Dnipropetrovshchyny 50-70-kh rokiv: monohrafiya [Music education of Dnepropetrovsk region 50-70s] Dnipro: LIRA, 2017. 184 p. [in Ukranian].

5. Medvednikova T. Maryya Heyman. Vydyushchyesya muzykanty Dnepropetrovshchyny [Maria Gaiman. Outstanding musicians of Dnipropetrovsk region]. D. : Dnepropetrovsk Conservatory named after M. Glinka, 2011. 180 p. [in Ukranian].

6. Medvednikova T. Mariam Gordon. Vydyushchiyesya muzykanty Dnepropetrovshchiny [Mariam Gordon. Outstanding musicians of Dnipropetrovsk region]. D.: Dnepropetrovsk Conservatory named after M. Glinka, 2008. P. 40. [in Ukranian].

7. Medvednikova T. Svetlana Gribanovskaya. Vydyushchiyesya muzykanty Dnepropetrovshchiny [Svetlana Gribanovskaya. Outstanding musicians of Dnipropetrovsk region]. D.: Dnepropetrovsk Conservatory named after M. Glinka, 2006. P. 9-10. [in Ukranian].

8. Medvednikova T. Lidiya Yevsevskaya. Vydyushchiyesya muzykanty Dnepropetrovshchiny [Lydia Evsevskaya. Outstanding musicians of Dnipropetrovsk region]. D.: Dnepropetrovsk Conservatory named after M. Glinka, 2007. P. 30-31. [in Ukranian].

9. Medvednikova T. Moisey Levin. Vydyushchiyesya muzykanty Dnepropetrovshchiny [Moisey Levin. Outstanding musicians of the Dnipropetrovsk region]. D.: Dnepropetrovsk Glinka Conservatory, 2014. 199 p. [in Ukranian].

10. Medvednikova T. Mikhail Oberman. Vydyushchiyesya muzykanty Dnepropetrovshchiny [Mikhail Oberman. Outstanding musicians of the Dnipropetrovsk region]. D.: M. Glinka Dnepropetrovsk Conservatory, 2013. 198 p. [in Ukranian]. 